\title{
Microbial Status of Fresh Cut Cooking Banana Variety Alukesel (Musa acuminata $\times$ Musa balbisiana, ABB Group) as Affected by Pre-Treatments
}

\author{
H. Siriwardana ${ }^{1}$ K. Abeywickrama ${ }^{1 *}$ and I. Herath ${ }^{2}$ \\ Received : 30 th July 2015 / Accepted : 05 th November 2015
}

\begin{abstract}
Fresh cut (minimally processed) cooking banana variety Alukesel was subjected to different pretreatments, packed in polystyrene packages and stored at 5-7 ${ }^{\circ} \mathrm{C}$ for a week. Effect of several identified pre-treatments on Total Plate Count (TPC) and Total Yeast and Mould counts (TYM) were evaluated. Bacteria isolated from plates were identified using biochemical tests and molecular tools. In pre-treated samples, microbial counts were within safe-to-consume limits. Bacillus cereus, Enterobacter ludwigii and Bacillus thuringiensis were identified from fresh cut samples using molecular tools. Citric acid at 3\% w/v effectively controlled bacteria, yeasts and moulds and this observation was significantly different from the control $(p<0.05)$. The present study has shown that 3\% citric acid was the most effective pretreatment for minimal processing of Alukesel which controlled bacteria, yeasts \& moulds completely. Alukesel pretreated with 3\% citric acid was free from food borne pathogens such as Salmonella, Clostridium, Yersinia, and Listeria.
\end{abstract}

Keywords: Minimal processing, Alukesel banana, pre-treatments, microbiological quality INTRODUCTION

Minimally processed products (fresh cuts) are fruits or vegetables subjected to a process of physical alteration such as cutting, trimming, slicing while ensuring that they retain the fresh state after processing (Moretti et al., 2000). The value of fresh cuts lies in the primary characteristics of freshness and convenience. Food safety, nutrition and sensory quality in fresh cuts have to be maintained at a high level, while providing extended shelf-life and freshness (Aguilar et al., 2004).

Fresh cuts deteriorate faster than intact produce. Physical damage during preparation of fresh cuts cause an increase in respiration rates, biochemical changes and microbial spoilage, which may result in deterioration of colour, texture and flavour of the commodity of concern (Aguilar et al., 2004).

Microbiological safety is one of the key factors to be considered during the preservation of fresh cuts. The number of microorganisms found on produce can vary according to product quality, product characteristics, resident micro-flora of the product, handling, processing, storage, distribution and retail display. Further, microbial growth is influenced by the physiology of the fresh cut product, pre- and post-harvest processing treatments and packaging (Watada, 1997).

Microorganisms found in the fresh cuts can be categorized mainly into two types namely, psychotropic and mesophilic. Some pectinolytic bacteria that can proliferate at low temperature are Bacillus spp., Xanthomonas compestris, Erwinia carotovora and Pseudomonas. Erwinia and Pseudomonas have a competitive advantage over other microorganisms that could potentially be harmful to humans (Hui et al., 2006). In terms of microbial safety, psychrotropic pathogens,

$I^{*}$ Department of Botany, University of Kelaniya, Sri Lanka.

2 Genetech Molecular Diagnostic \& School of Gene Technology, Colombo 08, Sri Lanka. 
such as Listeria monocytogenes, Aeromonas hydrophila and Yersinia enterocolitica and mesophiles such as Salmonella, Escherichia coli and Clostridium botulinum are of particular concern (Goularte et al., 2004). With sufficient time, several types of yeast and moulds also may grow to levels that cause food spoilage in fresh cuts (Hui et al., 2006).

During preparation of fresh cuts, produce are immersed in pre-treatment solutions at the final stage of handling operations. Compounds such as ascorbic acid, citric acid, sodium metabisulphite, sodium chloride and calcium chloride have been utilized throughout the world as suitable preservatives to manage microbial problems and reduce browning for maintaining quality of fresh cuts such as potato, apple (Ahvenainen, 1996), bell pepper (Ediriweera et al., 2012), Pineapple plus amberella (Daranagama et al., 2012), Ela Batu (Solanum surattense) (Dharmabandu et al., 2007) and Jak fruit (Latifah et al., 2007).

Microbiological qualities of certain fresh cuts have been previously reported. According to Kang and Lee (1997), total aerobic plate count in fresh cut green pepper ranged from 4.6 to $7.2 \log _{10} \mathrm{CFU} / \mathrm{g}$ during a 6 day storage period at $5{ }^{\circ} \mathrm{C}$. As reported by Nur Aida et al., (2007), in processed mung bean sprouts stored at $2{ }^{\circ} \mathrm{C}$, Total plate count (TPC) ranged between 7.05-7.46 $\log _{10} \mathrm{CFU} / \mathrm{g}$, while Total Yeast and Mould counts (TYM) varied between 2.05-4.15 $\log _{10} \mathrm{CFU} / \mathrm{g}$. According to Dharmabandu et al., (2007) mean aerobic plate counts of fresh cuts of Solanum surattense (Ela Batu) ranged between 66 to $133 \mathrm{CFU} / \mathrm{g}$. Microbial counts should be under the required legal limits to be considered safe to consume in any fresh cut meant for human consumption. Therefore, microbial quality is of dire significance in the preparation and storage of fresh cuts as value added products meant for consumers.

Cooking banana variety Alukesel belonging to family Musaceae is a hybrid derived from Musa acuminata and M. balbisiana, which contains a considerable amount of fiber, carbohydrate, vitamins and potassium (Simmonds, 1966). In Sri Lanka, variety Alukesel is commonly used in the preparation of savoury curries and fried chips. This commodity could be stored for longer periods intact, however undergoes browning soon after slicing. Banana thus stains the hands of the handler due to melanin formed on the cut surface. A recent investigation was carried out in our laboratory on the effect of selected pre-treatments on physicochemical / sensory properties and degree of browning of fresh cut Alukesel and the major findings have been published (Siriwardana et al., 2015). However, no research data are currently available on microbiological aspects of fresh cut Alukesel.

The objectives of current study were (1) to evaluate the microbial status of fresh cut Alukesel banana subjected to individual or combinations of pre-treatments of sodium chloride, calcium chloride, citric acid, ascorbic acid, and sodium metabisulphite stored at $5-7{ }^{\circ} \mathrm{C}$ for a week and (2) to identify bacteria associated with pre-treated Alukesel using molecular tools. If Alukesel banana is relatively free of hazardous food-borne pathogens and browning is managed, this type of value-added fresh cuts could be made available to local consumers for preparation of chips and curries.

\section{MATERIALS AND METHODS}

\section{Preparation of Alukesel banana}

Cooking banana variety Alukesel (Musa acuminata $\times$ Musa balbisiana, ABB Group) of 90 day maturity was purchased from supermarkets in Kiribathgoda, Sri Lanka and transported to the laboratory at the Department of Botany, University of Kelaniya. Banana were peeled and washed with distilled water, dipped in chilled water for $2 \mathrm{~min}$. Subsequently, the produce were cut into slices (8-10 g) using 
a sharp stainless steel knife under aseptic conditions. The resulting slices were separately dipped in selected pre-treatment solutions, singly or in combination, such as $3 \%(\mathrm{w} / \mathrm{v})$ ascorbic acid $\left(\mathrm{T}_{1}\right), 3 \%(\mathrm{w} / \mathrm{v})$ citric acid $\left(\mathrm{T}_{2}\right)$, $2 \%(\mathrm{w} / \mathrm{v})$ ascorbic acid $\left(\mathrm{T}_{3}\right), 2 \%(\mathrm{w} / \mathrm{v})$ citric acid $\left(\mathrm{T}_{4}\right), \quad 1.5 \%(\mathrm{w} / \mathrm{v})$ citric acid $+1.5 \%$ $(\mathrm{w} / \mathrm{v})$ ascorbic acid $\left(\mathrm{T}_{5}\right), 2 \%(\mathrm{w} / \mathrm{v})$ sodium metabisulphite $\left(\mathrm{T}_{6}\right), 2 \%(\mathrm{w} / \mathrm{v})$ calcium chloride $\left(\mathrm{T}_{7}\right), 2 \%(\mathrm{w} / \mathrm{v})$ sodium chloride $\left(\mathrm{T}_{8}\right)$ or distilled water (control) $\left(\mathrm{T}_{9}\right)$ for $5 \mathrm{~min}$. Samples were drained and air dried for $15 \mathrm{~min}$ and slices (810) were packed in polystyrene packages of 100 g capacity and sealed by placing clip-on lids (Latifah et al., 2000). Packages were labeled and placed on plastic trays $(30 \mathrm{~cm} \times 40 \mathrm{~cm})$ and stored in a cold room at $5-7{ }^{\circ} \mathrm{C}$ and $80-85 \%$ relative humidity. Four replicate packages were used per treatment.

\section{Assessment of microbiological properties}

Alukesel samples were subjected to the following microbiological assessments on day 0 (initial day) and after 7 days.

Total aerobic Plate Count (TPC): Twenty (20.0) g of Alukesel was homogenized with 180 $\mathrm{mL}$ of sterile $0.9 \% \mathrm{NaCl}$ (Merck Specialties Private Limited, India) in a blender for $2 \mathrm{~min}$ and a dilution series was prepared up to $10^{-5}$. From $10^{-3}, 10^{-4}$ and $10^{-5}$ dilutions, $1 \mathrm{~mL}$ was plated to $12 \mathrm{~mL}$ of molten plate count agar (PCA) (Oxoid Ltd., England). Plating was done in duplicate. Plates were incubated at $28 \pm 2{ }^{\circ} \mathrm{C}$ for 72 hours and colony forming units (CFU) were determined using the equation described by SLS Part 1 (1991). Four replicate samples were used per treatment.

Total Yeast and Mould count (TYM): One mL from $10^{-3}, 10^{-4}$ and $10^{-5}$ dilutions prepared under total aerobic plate count, were separately plated along with $12 \mathrm{~mL}$ molten yeast and mould agar (YMA). Plating was done in duplicate. Plates were incubated at $28 \pm 2{ }^{\circ} \mathrm{C}$ for 72 hours and CFUs were determined (Nur Aida et al., 2007). Four replicate samples were used per treatment.

\section{Identification of bacteria isolated from total plate count}

Pure cultures of bacteria were prepared by isolating bacteria from plates prepared for TPC which were grown on nutrient agar (NA) (Oxoid Ltd., England). The plates were incubated at $28 \pm 2{ }^{\circ} \mathrm{C}$ for 72 hours. Three sets of pure bacterial cultures were prepared and isolated bacteria were labeled as strain 1 (S1), strain 2 (S2), strain 3 (S3), strain 4 (S4) and strain 6 (S6). One set each of bacterial cultures was used to identify physiological and biochemical characters of bacteria through Gram's staining, endospore staining, motility determination, growth in oxygen environment, growth in anaerobic environment, catalase activity, acid and gas production from glucose, citrate utilization, methyl red test, indole production and lactose fermentation (Benson, 2002). Based on the results of biochemical tests, bacteria were identified up to the genus level with the aid of Bergey's Manual (Holt, 2000).

Another set of bacterial cultures was deposited in the Department of Botany, Culture collection (University of Kelaniya); a similar set of 2-day old cultures were subjected to PCR amplification and gene sequencing at Genetech Molecular Diagnostic \& School of Gene Technology, Colombo 8, Sri Lanka.

DNA Extraction and PCR amplification: Total genomic DNA was isolated from colonies of S1, S2, S3, S4 and S6 (on nutrient agar) using the Invitrogen PureLink Genomic DNA mini Kit (Cat No: K1820-01) and extracted DNA was stored in $100 \mu \mathrm{L}$ of TrisEDTA $\mathrm{pH}=8$ buffer at $-20{ }^{\circ} \mathrm{C}$. DNA was then used as a template for the amplification of the 16S rRNA region by using universal primers, 27F/800R and 518F/1492R (Lane et al., 1991, Turner et al., 1999).

Agarose gel Electrophoresis and PCR product purification: The amplified PCR product was visualized on a $2 \%$ agarose gel in $0.5 \mathrm{X}$ TBE containing ethidium bromide using a UV transilluminator (E-Gel imager, 
Life Technologies Israel). The band size was observed using an appropriate DNA molecular weight marker. PCR products were purified using the PureLink Quick Gel Extraction and PCR Purification Combo Kit (Invitrogen USA Cat No: K2200-01).

DNA Sequencing: Purified PCR products were subjected to DNA sequencing using BigDye ${ }^{\circledR}$ Terminator v3.1 Cycle Sequencing Kit (Applied Biosystem, USA, Part No. 4337455) and sequenced by programming the ABI Prism ${ }^{\circledR}$ 310 Genetic Analyzer (Applied Biosystem, USA). The 16s rRNA region sequence of the bacteria obtained, was compared with the available sequences in the National Center for Biotechnology Information (NCBI) database, using the BLAST program in order to identify bacteria to species/strain level.

\section{Statistical analysis}

The experimental arrangements of TPC and TYM were of completely randomized designs (CRD). Data obtained for microbiological properties were subjected to General Linear Model of ANOVA using MINITAB software. When significant effects were observed, treatment means were compared using Tukey's multiple comparison test at $\mathrm{p}=0.05$ significance level.

\section{RESULTS}

\section{Assessment of microbiological properties}

Total aerobic Plate Count (TPC): The TPC enumerated from samples of Alukesel on day 0 ranged from $2.78-4.42 \log _{10} \mathrm{CFU} / \mathrm{g}$ whereas, it ranged from zero to $4.64 \log _{10} \mathrm{CFU} / \mathrm{g}$ by day 7 . The TPC decreased by day 7 , when compared to day 0 , in most treatments except in 3\% ascorbic acid, $2 \%$ ascorbic acid, $1.5 \%$ citric acid $+1.5 \%$ ascorbic acid, 2\% sodium metabisulphite and control. On $7^{\text {th }}$ day after storage, the highest TPC of $4.64 \log _{10}$ CFU/g was observed in the $2 \%$ ascorbic acid pre-treated samples. Control also indicated a high total plate count value of $4.50 \log _{10} \mathrm{CFU} / \mathrm{g}$ by day 7. The lowest plate count of zero $\log _{10} \mathrm{CFU} / \mathrm{g}$ was observed in 3\% citric acid treated samples (Figure 01). Statistically significant difference $(p<0.05)$ was observed between day 0 and 7 for TPC of fresh cut Alukesel samples and the control when the effect of pre-treatment, time and interaction of pre-treatment $\mathrm{x}$ time was considered (Table 01).

Total Yeast and Mould count (TYM): The TYM count enumerated from samples on day 0 ranged from zero to 4.43 , which was somewhat similar to results seen on day 7 (zero to 4.10 $\log _{10} \mathrm{CFU} / \mathrm{g}$ ). On day 0, yeasts and moulds were not observed in distilled water samples while on day 7 no colonies were observed in 3\% ascorbic acid, 3\% citric acid, 2\% ascorbic acid, 1.5\% citric acid $+1.5 \%$ ascorbic acid and $2 \%$ sodium chloride treated Alukesel. In most pre-treated samples, yeast and mould counts decreased by day 7 , compared to day zero, except in $2 \%$ sodium metabisulphite indicating the antimicrobial activity of certain pre-treatments such as ascorbic acid, citric acid and sodium chloride (Figure 02). Control, by day 7 indicated a TYM count of $3.27 \log _{10} \mathrm{CFU} / \mathrm{g}$. There was a significant difference $(p<0.05)$ of TYM counts of samples compared to control when the effect of pre-treatment, time and interaction effect of pre-treatment $\mathrm{x}$ time were considered (Table $01)$.

\section{Identification of bacteria isolated from total plate count}

Based on biochemical tests conducted, five strains of bacteria were identified from TPC experiment (Table 02). Strains 1, 2, 3 and 6 were identified as Bacillus sp. and stain 4 as Enterobacter spp. 
During molecular identification based results obtained from NCBI BLAST tool, the identity of S1, S2, S3, S4 and S6 bacterial cultures were confirmed as Bacillus cereus, Bacillus cereus, Bacillus cereus, Enterobacter ludwigii and Bacillus thuringiensis. These results were deposited in Genebank under the accession numbers KT970720, KT970721, KT970722, KT970723 and KT970724.

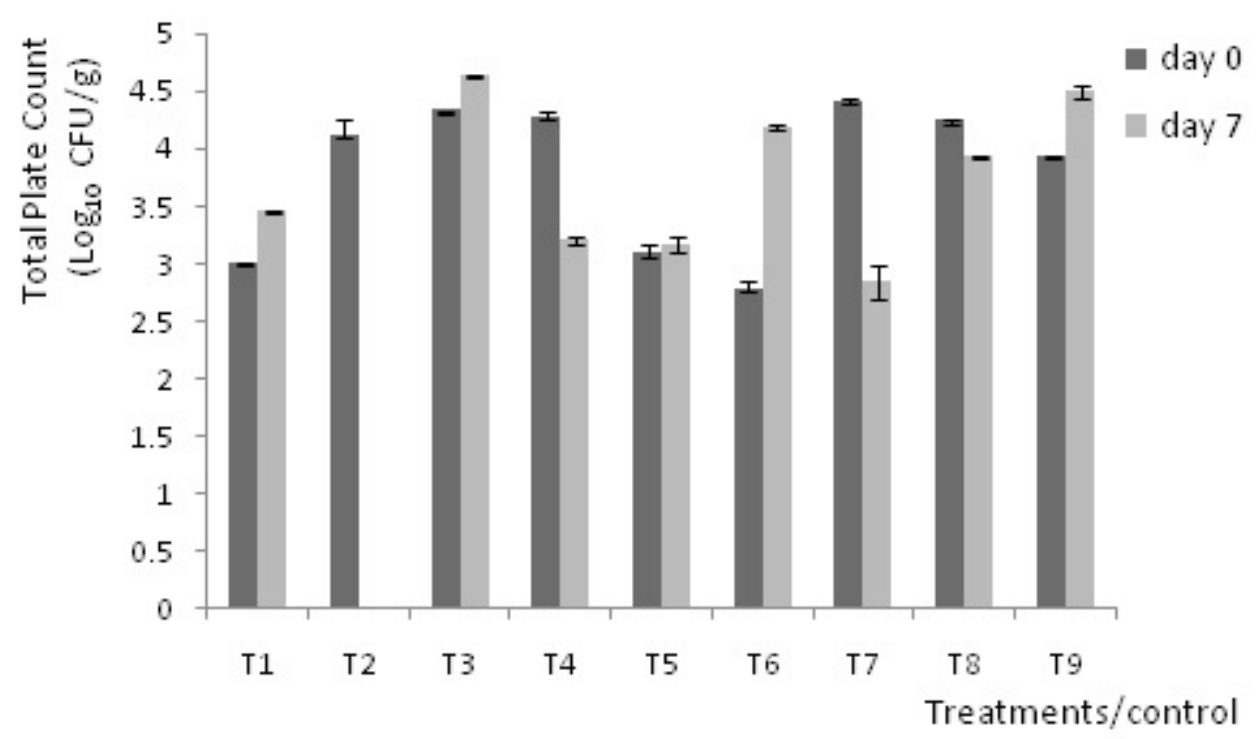

Figure 01: Effect of selected pre-treatments on TPC of fresh cut Alukesel banana, in comparison to control, 0 and 7 days after storage at $5-7{ }^{\circ} \mathrm{C} .\left(\mathrm{T}_{1}-3 \%\right.$ ascorbic acid, $\mathrm{T}_{2}-3 \%$ citric acid, $T_{3}-2 \%$ ascorbic acid, $T_{4}-2 \%$ citric acid, $T_{5}-1.5 \%$ citric acid $+1.5 \%$ ascorbic acid, $T_{6}-2 \%$ sodium metabisulphite, $T_{7}$ - calcium chloride, $T_{8}$ - sodium chloride, $T_{9}$ - distilled water (control)). Data points of TPC represent the mean of eight replicates \pm standard error.

Table 01: ANOVA of different pre-treatments and time on TPC and TYM count of fresh cut Alukesel.

\begin{tabular}{lccc}
\hline Factor & d.f. & F value & P value \\
\hline TPC & & & \\
A (pre-treatment) & 8 & 237.78 & 0.00 \\
B (time) & 1 & 229.86 & 0.00 \\
A $\times$ B & 8 & 304.6 & 0.00 \\
TYM & & & \\
A (pre-treatment) & 8 & 10.43 & 0.00 \\
B (time) & 1 & 40.15 & 0.00 \\
A $\times$ B & 8 & 11.25 & 0.00 \\
\hline
\end{tabular}

d.f. $=$ degrees of freedom

$\mathrm{P}<0.05$ indicates a significant difference among variables and control. 


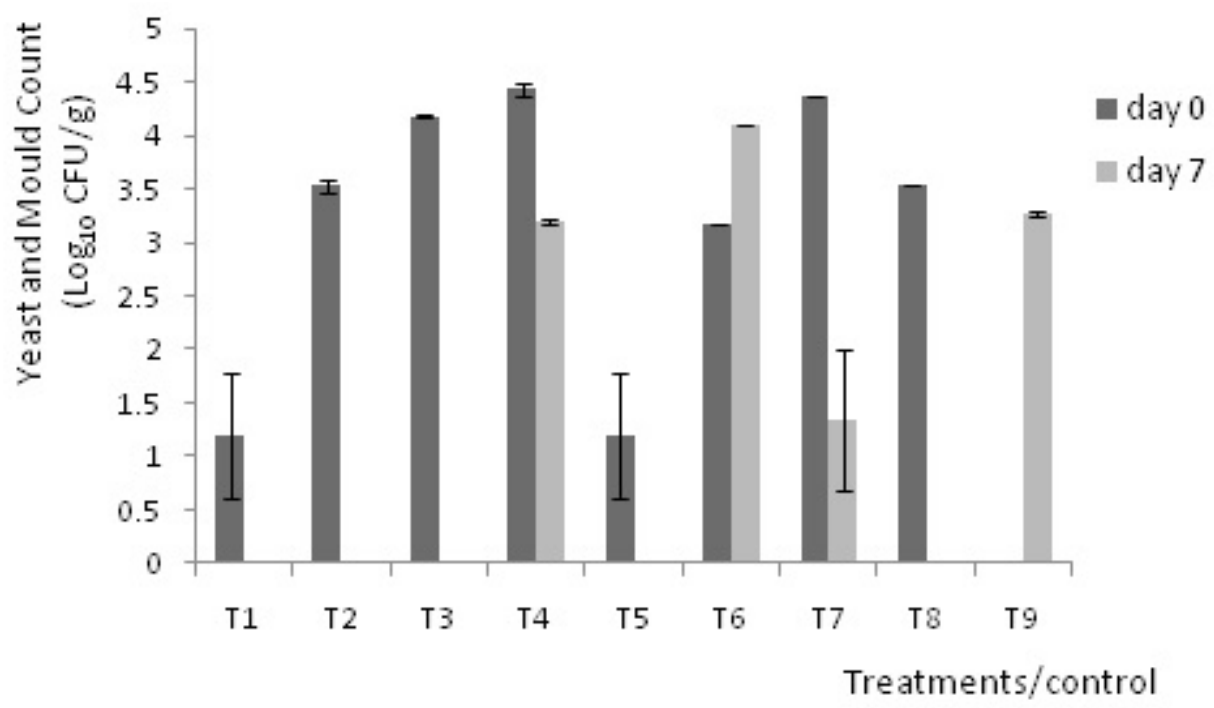

Figure 02: Effect of selected pre-treatments on TYM count of fresh cut Alukesel banana, in comparison to control, 0 and 7 days after storage at 5-7 ${ }^{\circ} \mathrm{C} .\left(\mathrm{T}_{1}-3 \%\right.$ ascorbic acid, $\mathrm{T}_{2}$ - $3 \%$ citric acid, $T_{3}-2 \%$ ascorbic acid, $T_{4}-2 \%$ citric acid, $T_{5}-1.5 \%$ citric acid + $1.5 \%$ ascorbic acid, $T_{6}-2 \%$ sodium metabisulphite, $T_{7}$ - calcium chloride, $T_{8}$ - sodium chloride, $T_{9}$ - distilled water (control)). Data points of TYM count represent the mean of eight replicates \pm standard error.

Table 02: Characteristics of bacteria associated with fresh cut Alukesel.

\begin{tabular}{|c|c|c|c|c|c|}
\hline Characteristics & Strain 1 & Strain 2 & Strain 3 & Strain 4 & Strain 6 \\
\hline Colony colour & White & White cream & White & Light yellow & White \\
\hline Colony shape & $\begin{array}{c}\text { Round with } \\
\text { irregular } \\
\text { margins }\end{array}$ & $\begin{array}{l}\text { Round with } \\
\text { irregular } \\
\text { margins }\end{array}$ & $\begin{array}{l}\text { Irregular and } \\
\text { spreading }\end{array}$ & $\begin{array}{c}\text { Round with } \\
\text { entire margins }\end{array}$ & $\begin{array}{c}\text { Round with } \\
\text { lobate margins }\end{array}$ \\
\hline Cell shape & Rod & Rod & Rod & Rod & Rod \\
\hline Gram`s reaction & + & + & + & - & + \\
\hline $\begin{array}{l}\text { Endospore } \\
\text { formation }\end{array}$ & + & + & + & - & + \\
\hline Motility & + & + & + & + & + \\
\hline $\begin{array}{l}\text { Growth under } \\
\text { Oxygen }\end{array}$ & + & + & + & + & + \\
\hline $\begin{array}{l}\text { Growth in } \\
\text { Anaerobic Jar }\end{array}$ & + & + & + & + & + \\
\hline $\begin{array}{l}\text { Acid production } \\
\text { from Glucose }\end{array}$ & - & - & - & - & - \\
\hline Citrate Utilization & - & - & - & + & - \\
\hline Catalase test & + & + & + & + & + \\
\hline Indole Production & - & - & - & - & - \\
\hline Methyl Red Test & - & - & - & - & - \\
\hline $\begin{array}{l}\text { Lactose } \\
\text { Fermentation }\end{array}$ & - & - & - & + & - \\
\hline
\end{tabular}




\section{DISCUSSION}

TPC providesinformation on themicroorganisms (especially bacteria) growing aerobically at 30 ${ }^{0} \mathrm{C}$, under the specified conditions (SLS Part 1, 1991). In Alukesel, there was a significant difference in the TPC between pre-treatments and the control, indicating the antimicrobial efficacy of pre-treatments used in this study. The most promising results in controlling TPC were displayed by Alukesel samples pretreated with $3 \%$ citric acid, which was able to control the microbial growth completely, by day 7 . It was also evident that the lower concentration of citric acid was less effective in controlling the microbial growth. According to a recent publication by our research group, it was reported that $3 \%$ citric acid pretreatment effectively controlled browning and maintained acceptable quality in fresh cut Alukesel (Siriwardana et al., 2015). Similarly, Daranagama et al., (2012) reported $4.93 \log _{10}$ CFU/g value for TPC for fresh cut ambarella (Spondias dulcis) and pineapple together as a mixed load, after pretreating with $1 \%$ citric acid and storing at $5-7{ }^{\circ} \mathrm{C}$ for seven days. Citric acid is one of the best known chelating agents, which can chelate $\mathrm{Cu}$ to control browning in minimally processed fruits and vegetables (Manolopoulou and Varzakas, 2011). Further, citric acid inhibits the growth of microorganisms by lowering the $\mathrm{pH}$ of processed commodity (Hui et al., 2006).

According to Kumari (2009), the microbial level of all pre-treated fresh cut samples of Lasia spinosa treated with $0.5 \%$ ascorbic acid increased, during the storage period of 7 days at $5-7^{\circ} \mathrm{C}$. This is in agreement with the present data as a slight increase in TPC could be observed for samples pre-treated with 3\% ascorbic acid, $2 \%$ ascorbic acid and $1.5 \%$ citric acid $+1.5 \%$ ascorbic acid by day 7 , when compared to day 0 . This may be possible as ascorbic acid can act as an intermediate in the metabolism and the growth rate of microorganisms, which can lead to slight increase in their proliferation. Sodium metabisulphite ( at $2 \%$ ) did not display antimicrobial effect as TPC increased after 7 days of storage, although the same treatment was relatively effective in controlling browning of fresh cut Alukesel as reported by Siriwardana et al., (2015).

The mesophilic aerobic bacterial counts on finished cut vegetables ranged depending on the commodities, season of the year and growing regions. According to Heard (2000), aerobial bacterial counts on bagged salads from the retail market ranged from 4.0-9.0 $\log _{10} \mathrm{CFU} / \mathrm{g}$. Allende et al., (2004) reported that initial aerobic mesophilic bacterial load on fresh cut baby spinach leaves after washing with $2.0 \mathrm{mM}$ chlorine was $7.2 \log _{10} \mathrm{CFU} / \mathrm{g}$. However, it was reported that microbial populations of fresh cut baby spinach leaves increased up to $9.0 \log _{10}$ $\mathrm{CFU} / \mathrm{g}$ level, during storage of 12 days at $5{ }^{\circ} \mathrm{C}$. According to Francis et al., (1999), the legal regulations on fresh cut vegetables established a maximum total limit of $7.7 \log _{10} \mathrm{CFU} / \mathrm{g}$ for TPC. In the present study, TPC ranged from zero to $4.64 \log _{10} \mathrm{CFU} / \mathrm{g}$ by day 7 . It is important to highlight at this point that the TPC counts of test samples from all pre-treatments of Alukesel did not exceed the legal limit indicating that the samples processed this way are safe to consume.

The TYM counts provide a general guidance for the enumeration of viable yeasts and moulds in products at specified conditions (SLS Part 2, 1991). TYM were found to be slightly lower than TPC for Alukesel samples ranging from $0-4.10 \log _{10} \mathrm{CFU} / \mathrm{g}$ on day 7. These results are also in agreement with those of Nur Aida et al., (2007) for minimally processed mung bean sprouts, where values ranged from 2.05 - $4.15 \log _{10} \mathrm{CFU} / \mathrm{g}$. According to Nur Aida et al., (2007) bacterial populations dominate over yeasts and moulds in vegetables. The yeasts and moulds were completely absent in the cooking banana samples pre-treated with 3\% ascorbic acid, $3 \%$ citric acid, $2 \%$ ascorbic acid, $1.5 \%$ citric acid $+1.5 \%$ ascorbic acid and $2 \%$ sodium chloride. Both ascorbic and citric acid inhibit the growth of yeasts and moulds by lowering 
the $\mathrm{pH}$ of processed commodity. Similarly, Ediriweera et al., (2012) reported zero yeast and mould counts for fresh cut bell pepper, treated with $1 \%$ sodium chloride and stored at $5-7{ }^{\circ} \mathrm{C}$ by day 7 . When sodium chloride is incorporated as a pre-treatment, high osmotic pressure results in plasmolysis of microbial cells causing dehydration and inhibition of growth of microorganisms. Further, chloride ion is toxic to most microorganisms (Hui et al., 2006). According to Nur Aida et al., (2007) the recommended limit for TYM of fresh cut produce is $5 \log _{10} \mathrm{CFU} / \mathrm{g}$. Since the TYM in all the pretreated samples did not exceed the recommended limit, fresh cuts of Alukesel can be considered safe to consume. In most of pre-treated Alukesel samples, yeast and mould counts on day 7 were controlled at zero level. Therefore no attempt was taken to identify yeast and moulds to genus or species level during present research.

Using molecular tools, bacteria isolated from TPC were identified as Bacillus cereus, Enterobacter ludwigii and Bacillus thuringiensis. B. cereus can readily be isolated from various food products. This species is common in nature, and may survive different stresses during food production due to chemical and heat resistant endospores. Some strains of B. cereus are harmful to humans and cause foodborne illness, while other strains can be beneficial as probiotics for humans (Doyle $e t$ al., 1989). B. thuringiensis is used worldwide as a biological insecticide due to its ability to produce crystal proteins with highly specific activity against certain insects. B. cereus and $B$. thuringiensis are closely related and genomic studies have proposed that they should be merged into a single species (Helgason et al., 2000). After commercialization of $B$. thuringiensis-based insecticides, studies have shown that $B$. thuringiensis like $B$. cereus produces enterotoxins responsible for human diarrhoea. B. thuringiensis has however, only in one case been described to be implicated in food borne disease (Jackson et al., 1995). One of the bacteria isolated and identified from Alukesel - E. ludwigii belongs to Enterobacter cloacae complex consisting six bacterial species which are widely encountered in nature. Some stains of this species are part of the commensal enteric flora of the human gastro-intestinal tract, while some strains include human pathogens and have been previously isolated in human clinical specimens (Mezzatesta et al., 2012). E. ludwigii has previously been isolated as an endophytic bacteria dwelling in strawberry fruit (De Melo Pereira et al., 2012).

This is the first report on the evaluation of microbial levels of fresh cut Alukesel, using molecular tools although related work on physicochemical/sensory properties and degree of browning of fresh cut Alukesel have been reported recently (Siriwardana et al., 2015). Although pre-treatments of ascorbic acid $(3 \%)$ and citric acid + ascorbic acid (1.5\% each) were better in controlling browning and sensory properties (Siriwardana et al., 2015), microbial growth was not controlled to a significant level, using the above individual or combined treatments. However, 3\% citric acid pre-treatment significantly reduced microbial growth by reducing TPC and TYM counts to zero level on day 7. As indicated by our previous research, Alukesel pre-treated with 3\% citric acid retained acceptable sensory properties and also managed browning to a greater extent (Siriwardana et al., 2015). Microorganisms such as Salmonella, Clostridium, Yersinia and Listeria are reported to be transmitted through contaminated food products, causing food borne diseases in humans and animals. Therefore, utmost care should be taken in identifying and quantifying microorganisms surviving on different commodities before any minimal processing technique is implemented on commercial scale in any country. However, no evidence of any of the above hazardous foodborne organisms were found during molecular identification of microorganisms from fresh cut Alukesel. 


\section{CONCLUSION}

In conclusion, the present study has shown that $3 \%$ citric acid was the most effective pretreatment for minimal processed Alukesel, which controlled bacteria, yeasts \& moulds completely. Alukesel pre-treated with 3\% citric acid was free from food borne pathogens such as Salmonella, Clostridium, Yersinia and Listeria.

\section{ACKNOWLEDGEMENT}

Authors gratefully acknowledge the financial assistance provided by the University of Kelaniya, Sri Lanka.

\section{REFERENCES}

Aguilar G.A.G., Zavala J.F.A., Cruz S.R., Felix E.A. and Cinco M.E.D. (2004). Effect of temperature and modified atmosphere packaging on overall quality of fresh-cut bell peppers. Lebensm-Wiss-U Technology. 37: 817-826.

Ahvenainen R. (1996). New approaches in improving the shelf life of minimally processed fruit and vegetables. Trends in Food Science and Technology. 7: 179-186.

Allende A., Luo Y., McEvoy J.L., Artes F. and Wang Y. (2004). Microbial and quality changes in minimally processed baby spinach leaves stored under super atmospheric oxygen and modified atmosphere conditions. Postharvest Biology and Technology. 33: 51-59.

Benson H.J. (2002). Microbiological Applications, Laboratory Manual in General Microbiology. $8^{\text {th }}$ Edition. McGraw Hill, Boston. 181pp.

Daranagama A., Ediriweera S. and Abeywickrama K. (2012). Pretreatments and cold storage on the quality of minimally processed Ambarella (Spondias dulcis L.) and the mixed load of Ambarella and pineapple (Ananas comosus (L.) Merr). Journal of Science of University of Kelaniya. 7: 21-41.

De Melo Pereira G.V., Magalhaes K.T., Lorenzetii E.R., Souza T.P. and Schwan R.F. (2012). A multiphasic approach for the identification of endophytic bacterial in strawberry fruit and their potential for plant growth promotion. Microbial Ecology. 63(2): 405-417.

Dharmabandu P.T.S., De Silva S.M., Wimalasena S., Wijesinghe W.A.J.P. and Sarananda K.H. (2007). Effect of pre-treatments on extending the shelf life of minimally processed "Ela Batu” (Solanum surattense). Tropical Agricultural Research and Extension. 10: 61-66.

Doyle M.P., Kramer J.M. and Gilbert R.J. (1989). Bacillus cereus and other Bacillus species. In: Foodborne Bacterial Pathogens (Doyle, M.P. Eds.). Marcel Dekker Incorporation., New York and Basel. 21-70.

Ediriweera S., Abeywickrama K. and Latifah M. (2012). Effect of chemical pretreatments on the quality of minimally processed pineapple stored in polystyrene packages. Ceylon Journal of Science (Biological Science). 41: 151-155.

Francis G.A., Thomas C. and O'beirne D. (1999). The microbiological safety of minimally processed vegetables. International Journal of Food Science and Technology. 34: 1-22. 
Goularte L., Martins C.G., Aizpurua I.C.M., Destro M.T., Franco B.D.G.M., Vizeu D.M., Hutzler B.W. and Landgraf M. (2004). Combination of minimal processing and irradiation to improve the microbiological safety of lettuce (Lactuca sativa, L.). Radiation Physics and Chemisty. 71: 155-159.

Heard G. (2000). Microbial safety of ready-to-eat salads and minimally processed vegetables and fruits. Food Science and Technology Today. 14: 15-21.

Helgason E., Okstad O.A., Caugant D.A., Johansen H.A., Fouet A., Mock M., Hegna I. and Kolsto A.B. (2000). Bacillus anthracis, Bacillus cereus, and Bacillus thuringiensis - one species on the basis of genetic evidence. Applied Environmental Microbiology. 66: 2627-2630.

Holt J. G., Noel R.K., Peter H.A.S., James T.S. and Stanley T.W. (2000). Bergey's manual of determinative bacteriology, $9^{\text {th }}$ Edition, Lippincott Williams \& Wilkins, USA.

Hui Y.H., Barta J., Cano M.P., Gusek T., Sidhu J.S. and Sinha K.S. (2006). Handbook of Fruits and Fruit Processing, $1^{\text {st }}$ Edition, Blackwell publishing, USA. 115-124.

Jackson S.G., Goodbrand R.B., Ahmed R. and Kasatiya S. (1995). Bacillus cereus and Bacillus thuringiensis isolated in a gastroenteritis outbreak investigation. Letters in Applied Microbiology. 21: 103-105.

Kang S.K. and Lee D.S. (1997). Susceptibility of minimally processed green pepper and cucumber to chilling injury as observed by apparent respiration rate. International Journal of Food Science and Technology. 32: 421-426.

Kumari L.S. (2009). Effect of pretreatment on extending shelf life of minimally processed rhizomes of Lasia spinosa. M.Sc. Dissertation, Department of Chemistry, Faculty of Science, University of Kelaniya, Sri Lanka.

Lane D.J. (1991). 16S/23S rRNA sequencing. In: Nucleic acid techniques in bacterial systematic (Stackebrandt, E. and Goodfellow, M. Eds.). John Wiley and Sons, New York, USA. 115175.

Latifah M.N., Abdullah H., Selamat M.M., Habsah M., Talib Y., Rahman K.M. and Jabir H. (2000). Shelf life of minimally processed pineapple. Journal of Tropical Agriculture and Food Science. 28: 79-85.

Latifah M.N., Abdullah H., Zaulia O., Aziz I.A., Faridah M.S., Salleh M.P., Pauziah M., Ahmad T.S. and Muhammad S.M.N. (2007). Handling technology of minimally processed pineapple and jackfruit for export by air shipment. Proceedings of the National Horticulture Conference, Malaysia, 69-73.

Manolopoulou E. and Varzakas T. (2011). Effect of storage conditions on the sensory quality, colour and texture of fresh-cut minimally processed cabbage with the addition of ascorbic acid, citric acid and calcium chloride. Journal of Food and Nutrition Sciences. 2: 956-963.

Mezzatesta M.L., Gona F. and Stefani S. (2012). Enterobacter cloacae Complex: Clinical Impact and Emerging Antibiotic Resistance. Future Microbiology. 7(7): 887-902. 
Moretti C.L., Washington L.C., Silva W.L.C. and Aravjo A.L. (2000). Quality attributes and carbon dioxide evaluation of bell peppers as affected by minimal processing and storage temperature. Proceedings of Fla-State Horticultural Society. 113: 295-296.

Nur Aida M.P., Zaulia O., Hairiyah M., Che Omar D. and Habsah M. (2007). Effect of washing treatment on microbial and sensory changes of mung bean sprouts. Proceedings of the National Horticulture Conference, Malaysia, 283-288.

Simmonds N.W. (1966). Bananas, $2^{\text {nd }}$ Edition, Tropical Agriculture Series, Longman, London.

Siriwardana H., Abeywickrama K. and Kannangara S. (2015). Effect of pre-treatments on quality of minimally processed cooking banana variety Alukesel (Musa acuminata $\times$ Musa balbisiana, ABB Group). Journal of Agricultural Sciences. 10:11-20.

Sri Lanka Standard 516: Part 1 (1991). General guidance for enumeration of microorganisms, colony count technique at $30{ }^{\circ} \mathrm{C}$. Microbiological test methods, Sri Lanka Standards Institution, Sri Lanka.

Sri Lanka Standard 516: Part 2 (1991). Enumeration of yeasts and moulds. Microbiological test methods, Sri Lanka Standards Institution, Sri Lanka. 512 pp.

Turner S., Pryer K.M.M., Iao V.P.W. and Palmer J.D. (1999). Investigating deep phylogenetic relationships among cyanobacteria and plastids by small subunit rRNA sequence analysis. Journal of Eukaryotic Microbiology. 46: 327-338.

Watada A.E. (1997). Quality maintenance of fresh-cut fruits and vegetables. Food Biotechnology. 44: 116-122. 